\title{
Analysis of Parenting Patterns on Student Motivatio
}

\author{
Nur Alfiyatur Rohmaniyah \\ Program studi Pendidikan Guru Sekolah Dasar, Universitas Muria Kudus, Kudus, Indonesia \\ Email: rohmahalfiyatur908@gmail.com
}

Khamdun

Program studi Pendidikan Guru Sekolah Dasar, Universitas Muria Kudus, Kudus, Indonesia

Email:khamdun@umk.ac.id

Eko Widianto

Program studi Pendidikan Guru Sekolah Dasar, Universitas Muria Kudus, Kudus, Indonesia

Email: tugas.ekowidianto@gmail.com

\section{A R T I C L E I N F O \\ Article history: \\ 1 Mei 2020 Received in \\ revised form \\ 11 Juni 2020 \\ Accepted 10 Juli 2020 \\ Available online 25 \\ Agustus 2020 \\ Kata Kunci: \\ Pola asuh, motivasi \\ belajar siswa \\ Keywords: \\ Parenting, student \\ learning motivation}

\begin{abstract}
A B S T R A K
Masih rendahnya tingkat kedisiplinan siswa jenjang SD yang menyebabkan dampak keberlanjutan bagi siswa. Masalah pada penelitian ini yaitu tingkat kedisiplinan siswa yangkurang dipengaruhi oleh kurang perhatiannya posisi orang tua terhadap anak. Penelitian ini bertujuan untuk mengetahui lebih mendalam posisi orang tua demokratis dalam pembentukan kedisiplinan belajar siswa kelas III SD. Menggunakan pendekatan kualitatif serta tipe deskriptif dalam penyajian data hasil Penelitian. Metode yang digunakan dalam pengumpulan data menggunakan metode pengamatan, wawancara, dan pencatatan lapangan.Hasil penelitian menunjukan bahwa posisi orang tua demokratis memiliki peranan yang begitu strategis dalam pembentukan kedisiplinan belajar siswa kelas III SD. Melalui gaya asuh demokratis orang tua mampu memberikan pendampingan belajar serta pembentukan budi pekerti siswa. Tidak hanya itu siswa juga telah dibiasakan oleh orang tua untuk beraktivitas secara teratur di lingkungan keluarga khusunya dalam kedisplinan belajar. Oleh karena itu posisi orang tua demokratis sangat berperan dalam pembentukan kedisiplinan belajar siswa. Adapun saran yang dapat diambil dari penelitian ini bagi orang tua diharapkan mampu memberikan pendampingan belajar yang baik kepada anak sehingga anak memiliki tingkat kedisiplinan dan minat belajar yang tinggi.
\end{abstract}

\section{A B S T R A C T}

The low level of discipline among elementary school students has resulted in a sustainable impact on students. The problem in this study is the level of student discipline which is less influenced by the lack of attention to the position of parents towards children. This study aimed to find out more about the position of democratic parents in the formation of discipline in learning for grade III SD students. This study used a qualitative approach and descriptive type in presenting the research data. The method used in data collection was using the method of observation, interviews, and field notes. The results showed that the position of democratic parents has a very strategic role in the formation of learning discipline for third grade elementary school students. Through the democratic parenting style, parents are able to provide learning assistance and the formation of student character. Not only have that students also been accustomed by parents to have regular activities in the family environment, especially in the discipline of learning. Therefore, the position of democratic parents plays a very important role in the formation of student learning discipline. The suggestions that can be taken from this study for parents are expected to be able to provide good learning assistance to children so that children have a high level of discipline and interest in learning.

\section{Introduction}

The world of education has now entered the 21 st century which is marked by education that is no longer focused on teachers, but education must be centered on students who prioritize students' problem-solving and critical thinking abilities (Nurlaelah \& Sispiyati, 2013; Siswanto, 2018; Hapsari, EE, Sumantri, MS, \& Astra, 2019). This must be owned by students in order to improve the quality of education in Indonesia. However, at this time, the government is actively making efforts that can be done to improve the quality of education in Indonesia. One of them is increasing the Human Resources (HR) of students. Efforts to improve Human Resources (HR) can be done by implementing the 2013 curriculum (Fitri, Saparahayuningsih \& Agustriana, 2017).

The 2013 curriculum seeks to make students play more active role in learning activities. The active role of students in learning activities will make students more confident. In addition to making students confident, it can also increase student motivation (Tino. T, 2019; Ibad et al., 2019). Increasing motivation to learn is very influential on student academic achievement, with care and good family guidance, students can achieve good achievements. Families are individuals who join the same household because of blood relations. Family is the first and foremost scope consisting of father, mother, and children who have the potential to carry out children's 
character development. The family is a group of people who live together in a joint residence and each member feels an inner connection so that it affects each other (Kobandaha, 2019; Indarto. W, 2015; Djamarah, 2014)

In the family environment, the one who play an important role in the success of children are parents. Parents see their children as children and the foundation of the future that must be guided and nurtured. Guiding by helping, training and so on, and nurturing in the sense of caring for, nurturing and educating him are the ways to make them become a smart child (Widana, 2016; Mulyasih \& Suryani, 2016). Lack of parental attention will affect children's achievement. In the learning process, there are two factors that can influence the success or failure of children's learning activities. The first factor is an internal factor. Which includes internal factors of student learning are factors that come from within the student himself such as: a) Motivation, a person's willingness to learn will be higher when accompanied by motivation, both internal and external, b) Ideals, Every human being has ideals in his life, including students, c) Talent. Besides intelligence, talent is a factor that has a big influence on the process and results of one's learning. Then, the second factor that affects children's learning success is external factors. External factors are factors that are big from outside the student such as a) Teachers, teachers who succeed in fostering students' willingness to learn, b) Families, parents are the closest in the family, therefore family is very influential in determining a student's interest in lessons c) Social Friends, Through association, students can be influenced by the direction of their interests by their friends, especially close friends, d) Environment, the environment plays a very important role in children's growth and development (Fauziah et al., 2017; Nuraini \& Laksono, 2019).

One of the factors contained in students is learning motivation. Motivation can be said to be the overall driving force within students that causes learning activities, which ensures the continuity of teaching and learning activities. Student motivation will function if given a stimulus from outside the student. (Sadirman, 2005; Djamarah, 2011). Learning motivation greatly affects student learning outcomes. Motivation to learn requires stimulation from others such as parents, teachers, who always encourage children to progress. This study will discuss the level of external motivation that will improve student achievement.

Based on the results of observations carried out at SDN 1 Pelemkerep to be precise in grade III, it showed that more than half of the students in the class admitted that they prefer playing on cellphones than studying. Students also provided information that their habits at home tended to spend time playing cellphones, watching television, and playing. This statement became stronger with the explanation given by the classroom teacher that more than half of the students in the class had low learning motivation. This occurs as a result of parents in providing less optimal care and assistance so that it has an impact on students' lack of learning motivation.

The same thing is also supported by many researchers. Research conducted by (Handayani, 2019) which stated that the environment is a major influence in the sustainability of human life. A happy family is the key to the child's success and emotional level. The habits of the child will show how the habits are carried out at home with their parents. As a result, the research conducted by Handayani stated that parenting styles have an important role in children's learning motivation. In addition, research was also carried out by (Fadhilah et al., 2018) which stated that parenting and parental participation affect student learning motivation. This is because parents are the first and foremost teachers of children. Parents should provide provisions for their children to form a quality future generation because in essence, the success of children's education is the responsibility of the parents. In addition, research conducted by (Wahyuni et al., 2019) stated that the key to children's success is through the daily care of the closest people. The closest person to the child's daily life is the parent. So parents have a very important role to increase the motivation and learning success of students.

\section{Method}

This study focused on procedures that produce qualitative data, expressions or data from the person himself / behavior which was carried out through observation. Through qualitative research, researchers used qualitative strategies to collect in-depth data or information about everything related to education. This study was used to conduct research in relation to the analysis of parenting styles to increase the learning motivation of grade III students at SDN 1 Pelemkerep, Mayong District, Jepara Regency. Temporary data obtained from observations carried out at SDN 1 Pelemkerep actually in grade III has a total number of 35 students. 35 students include 17 male students and 18 female students. Data collection technique is the most important step in research, because the main purpose of the research is to get data. Data collection used observation and interview methods, the draft interview questions can be seen in table 1 , and the observation draft can be seen in table 2 . 
Table 1. Interview Questions

\begin{tabular}{|c|c|}
\hline No. & Questions \\
\hline 1. & Are there rules for how to teach children in learning? \\
\hline 2. & How do parents apply parenting styles to children so that their children will automatically learn? \\
\hline 3. & Do you always spend time with your children, even if you just accompany them to study? \\
\hline 4. & How long and what activities do you do with the child? \\
\hline 5. & $\begin{array}{l}\text { Do you teach your child to be open about the learning he gets at school, the learning achievement, and the } \\
\text { learning value he gets at school? }\end{array}$ \\
\hline 6. & How is the motivation of the mother / father to invite the child to study every night? \\
\hline 7. & Can the home environment influence the formation of children's motivation to learn? \\
\hline 8. & Can the play environment influence the formation of children's motivation to learn? \\
\hline 9. & $\begin{array}{l}\text { Do parents give children the freedom to do what they want, for example following activities outside } \\
\text { school hours such as extracurricular activities and other activities? }\end{array}$ \\
\hline 10 . & How do you apply parenting styles to children to improve children's achievement / learning outcomes? \\
\hline 11. & $\begin{array}{l}\text { Have the children of the mother / father told their parents about the problems faced at school, especially } \\
\text { the problems of achievement and learning outcomes? }\end{array}$ \\
\hline 12. & Has your child ever talked about difficulties or problems at school? \\
\hline 13. & Do you always give directions to children in teaching and learning activities at home? \\
\hline 14. & Does the work of the parents take up time with the children and their parents? \\
\hline 15. & $\begin{array}{l}\text { How do parents give time for children to be able to communicate well, especially in the children's } \\
\text { achievements at school? }\end{array}$ \\
\hline
\end{tabular}

Table 2. Draft Observations

\begin{tabular}{|c|c|}
\hline Indicator & Observed aspects \\
\hline Authoritarian & a. Parents of children do not have good communication when studying or in daily activities. \\
\hline Parenting & $\begin{array}{l}\text { b. Parents tend to look for children's mistakes and always judge them when children get bad } \\
\text { grades. } \\
\text { c. Parents tend to give orders and prohibitions to children } \\
\text { d. Parents do not monitor children by targeting their children without paying attention to } \\
\text { their abilities. }\end{array}$ \\
\hline $\begin{array}{l}\text { Permissive } \\
\text { Parenting }\end{array}$ & $\begin{array}{l}\text { a. Parents educate children indifferently and are indifferent to their learning achievement in } \\
\text { school. }\end{array}$ \\
\hline & $\begin{array}{l}\text { b. Parents only prioritize materials, never accompany children to study and ignore children if } \\
\text { asked to help with school assignments. } \\
\text { c. Parents and children do not have a good intimacy and relationship in the family. }\end{array}$ \\
\hline $\begin{array}{l}\text { Democratic } \\
\text { Parenting }\end{array}$ & $\begin{array}{l}\text { a. Parents determine the rules by paying attention and considering children's learning } \\
\text { activities. } \\
\text { b. Parents provide direction to children in carrying out their learning activities. } \\
\text { c. Parents provide guidance with understanding in their learning. } \\
\text { d. Parents actively communicate with their children when asking for help in completing } \\
\text { homework or assignments. }\end{array}$ \\
\hline
\end{tabular}

\section{Result and Discussion}

\section{Distribution of Parenting Patterns}

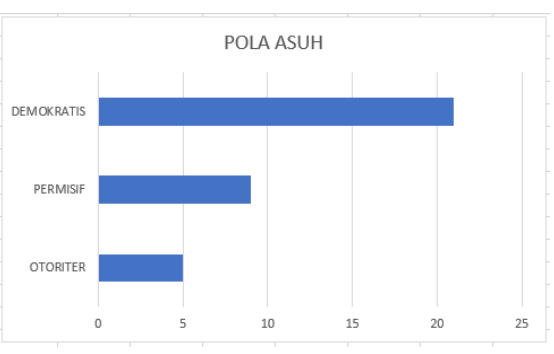

Figure 1. Distribution of Parenting Patterns 
From the results of interviews and observations, the results obtained are in accordance with Figure 1. Democratic parenting dominates the results of interviews and observations.

\section{Democratic Parenting}

The democratic parenting style was found to be dominant in the guardians of students; as many as 21 respondents used this parenting style. Democratic parenting prioritizes children's interests, but does not hesitate to control them. Parents who apply democratic parenting are able to place their children in their proper place, namely as individuals who are growing and developing and have their own initiative. This democratic parenting emphasizes the educational aspect so that parents often provide understanding, explanation, and assessment to help children why this behavior is expected (Lutfiyah et al., 2019; Suwanti, 2016). Democratic parenting has the characteristic of parents giving recognition in educating their children; they always encourage children to talk about what students want openly. Parents of students give freedom to students to choose what is best for them self; all their opinions are heard, responded to and given appreciation. Students are always involved in conversations, especially those concerning their future life (Masni, 2016; Pandia et al., 2015). This is in line with several previous studies on parenting styles by (Anisah, 2017) reviewing parenting patterns and their implications for the character building of children using a cross sectional approach.

Parents of students with democratic parenting will position their children in the same position as parents, meaning they have the same rights and obligations, parents have an attitude as givers of opinion and consideration of children's activities. Children will be more motivated when doing activities because of the confidence given by their parents, so that they are more responsible. This is in line with the statement of the guardian mother of grade III SDN 1 Pelemkerep Mayong Jepara in an interview. She said that democratic parenting is one of the parenting styles that makes children wise.

"The democratic parenting style is suitable to be applied in educating student discipline. Ojo students are based on their friends, the grandmother of students who are kakean is being treated by students of ISO Wedi Karo Wong Tuo, Wong Tuo must be patient with the children". (Interview conducted on June 28, 2020).

\section{Permissive Parenting}

Permissive parenting is in the second place, with 9 respondents applying this parenting pattern. Permissive parenting is characterized by parents giving full freedom to their children to act. Children are considered as mature people, who are given the freedom to do whatever they want. At this point, parental controls are very weak and may not even exist. Permissive parenting is usually called a neglectful parenting style, where parents prioritize their own interests, neglected children's personality development, and parents do not know what and how their children's daily activities (Adawiah, 2017; Suharsono et al., 2009)

Permissive parenting tends to give children freedom. By providing excessive freedom and without limits of control, let alone appearing to let the child confuse the child and the potential for the child to act misguided. This is in line with the statement of the mother in the interview conducted, she said: "It is not suitable to be applied in motivating student learning because children will not develop well or well without the supervision of parents all the time". (Interview conducted on June 28, 2020).

\section{Authoritarian Parenting}

Authoritarian parenting is characterized by parenting using many strict rules, forcing children to behave in accordance with the wishes of their parents, and limiting children's freedom to act on their own will. Parents who have such parenting always make all their own decisions and children must obey, obey and must not refuse or ask parents questions (Hidayati, 2014; Irmayani. N, 2017; Ayun, 2017)

This pattern is the parenting style that is the least adapted by the pupils. Authoritarian parenting tends to make children fearful, not growing up to be a person who likes to oppose, cheerful, likes to violate norms, is anxious and has a weak personality. Children who grow up with such nurturing techniques are usually unhappy and happy to be outside the house. The behavior of children who receive authoritarian care tends to be irritable, timid, gloomy, unhappy, easily influenced, easily stressed, has no clear and unfriendly future direction (Hidayati, 2014; Ayun, 2017)

This is in line with the disagreement in the use of authoritarian parenting by the third grade students of SDN 1 Pelemkerep Mayong Jepara in an interview, she said that it is true that if children are treated in a harsh way it will result in the characteristics of students who tend to be timid, loud and nasty. However, under certain conditions, parents of students need to apply authoritarian parenting to motivate student learning, and in certain situations parents also apply democratic parenting in motivating student learning.

Parents in providing the basics of disciplinary education to students, apply authoritarian parenting. However, it is authoritarian in certain limitations, namely in training the discipline of children learning, worshiping, discipline in doing homework and discipline in obeying the rules in the family. Parents of students are 
not always authoritarian and restrain all student activities, but students in their activities get restrictions and supervision from parents. This is as expressed by the class III guardian mother:

"I am sometimes harsh towards students, but in certain things, for example, children are playing during class and it's time to go to class, they have been summoned, why haven't I entered the class yet, I dragged his hand to enter the classroom. When I was teaching in class I was told to focus on the subject matter that I teach ". (Interview conducted on June 28, 2020).

\section{Geographical Conditions}

SDN 1 Pelemkerep is located in Pelemkerep Village and is located in Mayong District, Jepara Regency. Pelemkerep Village is located on the east side directly adjacent to Mayong Lor Village. Meanwhile, in the west it is directly adjacent to Pringtulis and Tunggul Pandean villages. If to the south it is connected to Mayong Lor Village, these boundaries are useful for separating each village so that the information obtained becomes more accurate.

There are complete infrastructure in Pelemkerep Village, Mayong District, Jepara Regency. In Pelemkerep Village, the road conditions can be said to be good, making it easier for residents to do activities. Transportation is also very busy because Pelemkerep Village is one of the northern routes to the Holy City. The residents also use electricity networks and communication tools to meet their daily needs. The facilities in Pelemkerep Village, Mayong District, Jepara Regency are very good because they can be enjoyed by its citizens as a whole. The facilities for communication and information media such as cellphones, telecommunications, internet, almost all residents in Pelemkerep Village already have them, even this is a basic need for residents in Pelemkerep Village, Mayong District, Jepara Regency.

\section{Parenting Influence Factors}

There are two factors supporting and inhibiting the application of parenting styles to students at SDN 1 Pelemkerep Mayong Jepara, including internal factors and external factors. These two factors can be inhibiting and supporting factors for parenting parents towards student learning motivation.

\section{Internal Factors}

1) Parents Age

The purpose of the law is as an effort in which every couple is able to be physically and psychosocially prepared to form a household and become parents. This is in line with the expression of a grade III teacher at SDN 1 Pelemkerep Mayong Jepara, namely: "The age factor plays a very important role when motivating student learning. Older parents can cause limitations in educating students to motivate learning."

\section{2) Parental Involvement}

The latest approach used in the relationship between father and newborn is as important as the relationship between mother and baby so that in the delivery process, the mother is advised to be accompanied by her husband and once the baby is born, she is allowed to carry her immediately after the mother holds her and breastfeeds.

This is in accordance with an interview with a grade III teacher at SDN 1 Pelemkerep Mayong Jepara, "Parents should be involved in educating and motivating students' learning, especially with regard to student motivation, because children must always be motivated by their parents regularly so that they can become studious and responsible people". (Interview conducted on 28 June 2020).

\section{3) Parents Busyness}

Busy parents at work and lack of time to gather with families so that students' daily activities are less controlled from parental supervision, can be an obstacle for parents in motivating student learning.

This is in line with the results of an interview with a grade III teacher at SDN 1 Pelemkerep Mayong Jepara, she said: "Busy parents can cause children to get less attention, so that children play alone with their friends without parental control." (Interview conducted on 28 June 2020).

\section{External Constraints}

\section{1) Living environment}

The environment where a family lives will affect how parents apply parenting styles. This can be seen from a family where they live in a good environment and there are many religious leaders, so parents may not be so worried if their children go around alone.

\section{2) Culture}

The culture of a place to live will affect the parenting style of parents. For example, parents who maintain the traditional concept of the role of parents that their parents are successful in motivating student learning are 
good, then they use the same techniques in motivating learning and caring for their children. The rapid flow of globalization such as television, games on mobile phones and the Internet.

The rapid flow of globalization greatly influences the application of parenting because the presence of media such as the internet, television, cellphones all broadcast films that are popular with students, students tend to feel lazy and even prefer to watch favorite films and this is certainly one of the things. which hinders parents from motivating student learning.

\section{Conclusion}

Based on the research results, the discussion of parenting styles in increasing student motivation can be concluded that democratic parenting is the dominant parenting style found in student guardians. The parenting style applied by parents in increasing learning motivation in students varies with the educational level of the parents and the age of the students. Democratic parenting is very suitable to be applied in motivating student learning and if parents use democratic parenting, students will be happy; parents do not let students or let the students freely. Then the supporting and inhibiting factors that affect the parenting style of parents in Pelemkerep Mayong Jepara village are divided into two: first, internal factors that come from within the family, for example, parental education, parental age, parental involvement, and parental activity. Second, external factors, namely factors originating from outside such as factors caused by the environment where they live, cultural culture, and the rapid flow of globalization such as television, games on cellphones and the internet.

\section{References}

A.M, Sardiman. (2016). Interaksi Dan Motivasi Belajar Mengajar. Jakarta: Pt Raja Grafindo Persada.

Amsyari, Fuad. (2018). Prinsip-prinsip Masalah Pencemaran Lingkungan. Jakarta Ghalia Indonesia.

Ananda, Rizka. Membangun Karakter Positif Buah Hati. Yogyakarta: Razan Media Press, 2017, Vol. 3 No.01

Anisah, Ani Siti. (2019). Pola Asu Orang Tua dan Implikasinya Terhadap PembentukanKarakter Anak. Jurnal Pendidikan Universitas Garut. Vol. 05; No. 01; 2018; 70-84.

Ayun, Q. (2017). Pola asuh orang tua dan metode pengasuhan dalam membentuk kepribadian anak. ThufuLA: Jurnal Inovasi Pendidikan Guru Raudhatul Athfal, 5(1), 102-122.

Damsar. (2017). Pengantar Sosiologi Pendidikan. Jakarta: Kencana.

Djali. (2019). Psikologi Pendidikan. Jakarta: Bumi Aksara.

Djamarah, S. B. (2014). Pola asuh orang tua dan komunikasi dalam keluarga. Jakarta: Rineka Cipta, 112.

Djamarah, Syaiful Bahri. 2014. Pola Asuh Orang Tua dan Komunikasi dalam Keluarga : Upaya Membangun Citra Membentuk Pribadi Anak. Jakarta : Rineka Cipta. Jurnal Kreatif Fabruari 2017.

Fauziah, A., Rosnaningsih, A., \& Azhar, S. (2017). Hubungan antara motivasi belajar dengan minat belajar siswa kelas IV SDN Poris Gaga 05 kota Tangerang. Jurnal JPSD, 4(1), 47-53.

Fitri, A., Saparahayuningsih, S., \& Agustriana, N. (2017). Perencanaan Pembelajaran Kurikulum 2013 Pendidikan Anak Usia Dini. Jurnal Ilmiah Potensia, 2(1), 1-13.

Handayani, R. (2019). Pengaruh Lingkungan Tempat Tinggal Dan Pola Asuh Orangtua Terhadap Motivasi Belajar Siswa Sekolah Dasar. Tunas Bangsa Journal, 6(1), 15-26.

Hapsari, E. E., Sumantri, M. S., \& Astra, I. M. (2019). Strategi Guru Meningkatkan Hasil Belajar Menggunakan Pendekatan Saintifik di Sekolah Dasar. Jurnal Basicedu, 3(3), 850-860.

Harianti, rini, dkk. 2016. Pola Asuh Orang Tua dan Lingkungan Pembelajaran Terhadap Motivasi Belajar Sswa. Jurnal curricula, Vol. 1, No. 2 (2016).

Ibad, Z., Sukestiyarno, Y. L., \& Hidayah, I. (2019, January). Peran Modul Kontekstual pada Model Discovery Learning untuk Meningkatkan Kemampuan Berpikir Kreatif dan Kemandirian Siswa. In Seminar Nasional Pendidikan Matematika Ahmad Dahlan (Vol. 6).

Irmayanti, N. (2016). Pola Asuh Otoriter, Self Esteem Dan Perilaku Bullying. Jurnal penelitian psikologi, 7(1), 20-35. 
Iskandar, M., \& Indarto, S. L. (2015). Interaksi Indepedensi, Pengalaman, Pengetahuan, Due Professional Care, Akuntabilitas dan Kepuasan Kerja Terhadap Kualitas Audit. Jurnal Ekonomi Dan Bisnis, 18(2), 1-16.

Kobandaha, I. M. (2019). Keluarga sebagai Basis Pendidikan Karakter. Irfani, 15(1), 81-92.

Motivasi Belajar. Jurnal ALIBKIN Vol 5, No 5 (2017)

Mulyasih, P. S., \& Suryani, N. (2016). Pengaruh Disiplin Belajar, Lingkungan Keluarga, dan Motivasi Belajar Terhadap Prestasi Belajar Mata Pelajaran Pengantar

Administrasi. Economic Education Analysis Journal, 5(2), 602-602.

Nashar. (2018). Peranan Motivasi dan Kemampuan Awal dalam Kegiatan Pembelajaran. Jakarta: Delia Press, Vol 12 No. 1, April 2018.

Nurafifah, F., Nurlaelah, E., \& Sispiyati, R. (2013). Perbandingan Peningkatan Kemampuan Berpikir Kritis Siswa SMP Antara yang Memperoleh Pembelajaran Means-Ends Analysis (MEA) dan Problem Based Learning (PBL). Jurnal Pengajaran MIPA, 18(1), 1-8.

Nuraini, N. L. S., \& Laksono, W. C. (2019). Motivasi Internal dan Eksternal Siswa Sekolah Dasar pada Pembelajaran Matematika. Sekolah Dasar: Kajian Teori dan Praktik Pendidikan, 28(2), 56-64.

Pandia, W. H., Munir, A., \& Azis, A. (2015). Hubungan harga diri siswa dan pola asuh demokratis orangtua dengan motivasi belajar siswa. Analitika: Jurnal Magister Psikologi UMA, 7(2), 80-87.

Panjaitan Putra, Ade, dkk. 2019. Korelasi dan Pendidikan. Jakarta: Pustaka Obor.

Rostiana, Irma. (2020). Hubungan Pola Asuh Orang Tua Dengan Motivasi Anak Untuk Bersekolah Di Kelurahan Sukagalih Kecamatan Sukajadi Kota Bandung. Journal Sosietas, Vol. 5, No. 2.

Setiawati, eka. 2015. Pengaruh Pola Asuh Terhadap Kedisiplinan Belajar Siswa. Jpurnal Of Elementary Education 2 (1) (2016).

Shochib, Moh. (2017). Pola Asuh Orang Tua (Dalam Membantu Anak Mengembangkan Disiplin Diri). Jakarta: PT Rineka Cipta

Shocib, M. 2019, Pola Asuh Orang Tua, Rineka Cipta, Jakarta. Volume 4, N0.3, November 2019.

Shocib, Moh. 2019. Pola Asuh Orang Tua Dalam Membantu Anak Mengembangkan Disiplin Diri. Jakarta: Rineka Cipta.

Siswanto, R. D., Dadan, D., Akbar, P., \& Bernard, M. (2018). Penerapan Model Pembelajaran Kooperatif Tipe Auditorial, Intelectually, Repetition (Air) Untuk Meningkatkan Pemecahan Masalah Siswa Smk Kelas XI. Journal on Education, 1(1), 66-74.

Slameto. (2017). Belajar Dan Faktor-Faktor Yang Mempengaruhinya. Jakarta: PT Rineka Cipta, Vol. 12 No. 1, April 2017.

Suharjo. (2016). Mengenal Pendidikan Sekolah Dasar Teori dan Praktek. Jakarta: Direktorat Jenderal Pendidikan Tinggi, Volume. 4, No.1, Februari 2018.

Suharsono, J. T., Fitriyani, A., \& Upoyo, A. S. (2009). Hubungan pola asuh orang tua terhadap kemampuan sosialisasi pada anak prasekolah di TK Pertiwi Purwokerto Utara. Jurnal keperawatan soedirman, 4(3), 112-118.

Suwanti, I., \& Suidah, H. (2016). Hubungan Pola Asuh Orang Tua Dengan Mental Emosional Pada Anak Usia Prasekolah (4-6 Tahun). Jurnal Keperawatan, 9(2), 10-10.

Syah, Muhibbin. (1999). Psikologi Pendidikan Suatu Pendekatan Baru. Bandung: PT Remaja. Vol.5 No. 2 (2017) 93-196.

Tino, T. (2019). Peran Aktif Teknik Pembelajaran Self Esteem Approach Sebagai Upaya Untuk Meningkatkan Prestasi Belajar Matematika Pada Siswa Kelas VIII-C Semester Genap Di SMP Negeri 1 Ngadirojo, Kabupaten Pacitan Tahun Pelajaran 2017 2018. Jurnal Revolusi Pendidikan (JUREVDIK), 2(2), 90-95.

Tri, Suharsono Joko, dkk. (2019). Hubungan Pola Asuh Orang Tua Terhadap Kemampuan Sosialisasi Pada Anak Prasekolah Di TK Pertiwi Purwokerto Utara. Jurnal Keperawatan Soedriman (The Soedirman Jpurnal Of Nursing), Volume 4, No.3, November 2019. 
Uno, H. B. (2017). Teori Motivasi Dan Pengukurannya: Analisis Di Bidang Pendidikan. Jakarta: Bumi Aksara, Vol.1, No. 2 (2016).

Utami, Nabilah Kartiyasa. (2017). Hubungan Antara Pola Asuh Orang Tua Dengan

Wahyuni, E. T., Rapani, R., \& Supriyadi, S. (2019). Hubungan Pola Asuh Orang Tua dan Motivasi Belajar dengan Hasil Belajar. Jurnal Pedagogi, 1(8).

Widana, I. W., Parwata, I. M. Y., Parmithi, N. N., Jayantika, I. G. A. T., Sukendra, K., \& Sumandya, I. W. (2018). Higher order thinking skills assessment towards critical thinking on mathematics lesson. International journal of social sciences and humanities, 2(1), 24-32.

Winarsih, Varia. (2019) Psikologi Pendidikan. Medan: Latansa Pers. Vol 5 No. 2 (2017) 93-196.

Yuliastuti, Eka Maulita. (2019). Pengaruh Pola Asuh Orang Tua Terhadap Motivasi Belajar Siswa Kelas VII di SMP Kristen 2 Salatiga. Journal Psikologi Konseling Vol. 15 no.2 2019. 